\title{
Analisis strategi pengembangan perikanan pukat cincin di Kecamatan Tuminting Kota Manado Provinsi Sulawesi Utara
}

\author{
Strategic analysis for purse seine fisheries development in Tuminting District, Manado, \\ North Sulawesi
}

\author{
DeYSy M. PUANSALAING*, JOHNY WenNo dan HENRY J. KuMAJAS.
}

Program Studi Pemanfaatan Sumberdaya Perikanan, Fakultas Perikanan dan Ilmu Kelautan, Universitas Sam Ratulangi, Manado 95115

\begin{abstract}
The most dominant fishery resources utilization and that of giving highest contribution to increase community welfare is by using purse seine, nevertheless purse seine can also be a threat to the resources. A strategic analysis is, therefore, required to develop purse seine fishery. This study aims to formulate and analyze the strategy to develop purse seine fishery in Tuminting District. The results showed that the highest priority is to increase production with a score of 1.8773 and the lowest priority is to maximize the use of TPI to maintain price stability with a score of 0.4254
\end{abstract}

Keywords: purse seine, strategy, score

\begin{abstract}
ABSTRAK
Pemanfaatan sumberdaya perikanan yang paling dominan dan memberikan pengaruh paling besar bagi peningkatan kesejahteraan bagi masyarakat adalah dengan alat tangkap pukat cincin, sekalipun demikian pukat cincin dapat menjadi ancaman bagi sumberdaya. Itulah sebabnya analisis strategi untuk pengembangan perikanan pukat cincin sangat diperlukan. Penelitian ini bertujuan untuk merumuskan dan menganalisis strategi pengembangan perikanan pukat cincin di Kecamatan Tuminting. Hasil penelitian menunjukkan bahwa skala proritas tertinggi adalah peningkatan produksi dengan skor 1,8773 dan skala prioritas terendah adalah tingkatkan fungsi TPI untuk menjaga stabilitas harga dengan skor 0,4254 .
\end{abstract}

Kata-kata kunci: pukat cincin, strategi, skor

\section{PENDAHULUAN}

Pengembangan penangkapan ikan pada hakekatnya berarah pada pemanfaatan sumberdaya ikan secara optimal dan rasional bagi kesejahteraan masyarakat pada umumnya dan nelayan khususnya, tanpa menimbulkan kerusakan sumberdaya ikan itu sendiri maupun lingkungan. UU No. 31/2004 tentang perikanan juga mengamanatkan bahwa pengelolaan perikanan, termasuk kegiatan perikanan tangkap harus dilakukan berdasarkan asas manfaat, keadilan, kemitraan, pemerataan, keterpaduan, keterbukaan, efisiensi, dan kelestarian yang berkelanjutan.

\footnotetext{
* Alamat untuk penyuratan; email: deysymaryapuansalaing@yahoo.com
}

Untuk mencapai hasil yang optimal dalam pengelolaan sumberdaya perikanan, tidak dapat lepas dari pendekatan pengelolaan sistem dinamik, karena bagaimanapun, sumberdaya perikanan adalah sumberdaya yang dinamis. Sumberdaya perikanan adalah aset yang dapat bertambah dan berkurang. baik secara alamiah maupun karena intervensi manusia. Seluruh dinamika alam dan intervensi ini mempengaruhi baik langsung maupun tidak langsung terhadap kondisi sumberdaya perikanan tersebut sepanjang waktu (Fauzi dan Anna, 2005).

Selama ini masyarakat nelayan identik dengan masyarakat miskin dan terpinggirkan, tetapi jika dikaitkan dengan potensi sumberdaya pesisir dan laut yang ada di perairan Indonesia yang menyimpan banyak manfaat, seharusnya dapat 
meningkatkan kesejahteraan masyarakat nelayan (Elier, 2007).

Pemanfaatan sumberdaya perikanan yang paling dominan dan memberikan sumbangsih paling besar bagi peningkatan kesejahteraan bagi masyarakat adalah pukat cincin, sekalipun demikian pukat cincin dapat menjadi ancaman bagi sumberdaya. Itulah sebabnya analisis strategi untuk pengembangan perikanan pukat cincin sangat diperlukan. Penelitian ini bertujuan untuk merumuskan dan menganalisis strategi pengembangan perikanan pukat cincin.

\section{METODE PENELITIAN}

\section{Metode pengumpulan data}

Metode yang digunakan dalam pengumpulan data adalah metode survei sedangkan pengambilan data menggunakan purposive sampling, yaitu memilih sampel berdasarkan kepentingan penelitian.

Penelitian dilakukan untuk menentukan strategi penangkapan ikan sehingga diharapkan dapat menunjang kehidupan nelayan. Jenis alat penangkapan ikan yang dijadikan sebagai obyek penelitian harus memenuhi salah satu syarat berikut, yaitu:

1) Jumlah alat tangkap banyak,

2) Jumlah sedikit tetapi hasil tangkapan totalnya besar,

3) Jumlah dan hasil tangkapan totalnya sedikit tetapi nilai dari hasil tangkapannya tinggi.

Berdasarkan syarat tersebut maka alat tangkap yang dijadikan objek penelitian adalah pukat cincin. Dengan demikian maka responden mempunyai tingkat homogenitas yang tinggi supaya jumlah sampel yang diambil dapat mewakili populasi

\section{Analisis data}

Data dianalisis dengan menggunakan SWOT yaitu identifikasi berbagai faktor secara sistematis untuk merumuskan strategi. Analisis ini didasarkan pada logika yang dapat memaksimalkan Kekuatan (Strength) dan Peluang (Opportunity), namun secara bersamaan dapat meminimalkan Kelemahan (Weakness) dan Ancaman (Threats) (Rangkuti, 2006).

Identifikasi faktor-faktor internal dan eksternal dibuat dalam tabel IFAS (Internal Factor Analysis Summary) dan EFAS (Eksternal Factor Analysis Summary). Untuk merumuskan faktor-faktor strategis internal dan eksternal tersebut dalam kerangka Kekuatan dan Kelemahan, Peluang dan Ancaman, tahapannya adalah sebagai berikut:

a. Beri bobot masing-masing faktor dengan skala mulai dari 0,0 (untuk faktor yang tidak penting) sampai dengan 1,0 (untuk faktor yang paling penting). Berdasarkan pengaruh faktor-faktor tersebut terhadap posisi strategis. Semua bobot tersebut jumlahnya tidak boleh melebihi skor total 1,00).

b. Hitung rating untuk masing-masing faktor dengan memberikan skala mulai dari 1 (pengaruhnya paling lemah) sampai dengan 4 (pengaruhnya paling kuat). Faktor yang bersifat positif (semua variabel yang masuk kategori kekuatan) diberi nilai mulai dari +1 sampai dengan +4 , sedangkan variabel yang bersifat negatif (semua variabel yang masuk kategori kelemahan) adalah kebalikannya.

c. Kalikan bobot dengan rating untuk memperoleh faktor pembobotan. Hasilnya berupa skor pembobotan untuk masing-masing faktor.

\section{HASIL DAN PEMBAHASAN}

\section{Keadaan umum daerah penelitian}

Kecamatan Tuminting merupakan salah satu kecamatan yang terletak di wilayah pesisir dan secara keseluruhan mempunyai sepuluh kelurahan. Kelurahan-kelurahan tersebut adalah Sindulang Satu, Sindulang Dua, Maasing, Bitung Karangria, Tumumpa Satu, Tumumpa Dua, Islam, Sumompo, Tuminting, dan Mahawu. Dari 10 kelurahan tersebut ada beragam profesi yang digeluti oleh masyarakat, di antaranya PNS, swasta, nelayan, tani, dagang, dan TNI/POLRI. Kelurahankelurahan yang masyarakatnya berprofesi sebagai nelayan dalam jumlah yang cukup besar yaitu Sindulang Satu, Sindulang Dua, Maasing, Bitung Karangria, dan Tumumpa Dua.

Tabel 1. Keadaan penduduk berdasarkan pekerjaan

\begin{tabular}{clcr}
\hline No & Pekerjaan & Jumlah & \multicolumn{1}{c}{$\%$} \\
\hline 1. & PNS & 1030 & 7,55 \\
2. & Wiraswasta & 8145 & 59,53 \\
3. & Pedagang & 2932 & 21,43 \\
4. & Nelayan & 1214 & 8,87 \\
5. & Petani & 104 & 0,76 \\
6. & TNI/Polri & 255 & 1,86 \\
\hline & Jumlah & 13680 & 100 \\
\hline
\end{tabular}




\section{Hasil penelitian}

Hasil wawancara dengan menggunakan kuesioner terhadap 100 orang responden pada empat kelurahan yang dijadikan sampel yaitu Kelurahan Tumumpa Dua, Kelurahan Maasing, Kelurahan Sindulang Satu, dan Kelurahan Bitung Karangria diperoleh faktor-faktor strategi internal seperti pada Tabel 2 dan faktor-faktor strategi eksternal seperti pada Tabel 3.
Setelah faktor-fakor strategis internal dan eksternal dirumuskan, dilanjutkan dengan pemberian bobot, rating, dan skor. Tabel 2 dan 3 memperlihatkan bahwa total skor pada unsur Kekuatan sebesar 1,8631, skor pada unsur Kelemahan sebesar 0,7578, skor pada unsur Peluang sebesar 1,6468, dan skor pada Ancaman sebesar 0,7733. Unsur Kekuatan memiliki skor yang tinggi. Hal ini mengartikan bahwa perikanan

Tabel 2. Matriks faktor internal

\begin{tabular}{|c|c|c|c|c|}
\hline Kode & Unsur SWOT & Bobot & Rating & Skor \\
\hline & Internal & & & \\
\hline & Kekuatan & A & B & $\mathrm{A} \times \mathrm{B}$ \\
\hline K1 & Produktifitas cukup besar & 0,1383 & 4 & 0,5532 \\
\hline $\mathrm{K} 2$ & Jaringan pemasaran dekat dengan konsumen & 0,1034 & 4 & 0,4136 \\
\hline K3 & Jumlah nelayan cukup besar & 0,0689 & 4 & 0,2756 \\
\hline K4 & Jangkauan alat tangkap luas dalam menangkap ikan & 0,0344 & 3 & 0,1032 \\
\hline K5 & Memiliki nilai analisis usaha yang menguntungkan & 0,1383 & 2 & 0,2766 \\
\hline K6 & Tersedianya kapal, alat tangkap dan rumpon & 0,0344 & 2 & 0,0688 \\
\hline K7 & Tersedianya galangan kapal rakyat & 0,0344 & 3 & 0,1032 \\
\hline K8 & Tersedianya pabrik es & 0,0689 & 1 & 0,0689 \\
\hline \multirow[t]{2}{*}{ Total } & & & & 1,8631 \\
\hline & Kelemahan & & & \\
\hline L1 & Tidak adanya pencatatan dan penyajian data tangkap nelayan & 0,1034 & 2 & 0,2068 \\
\hline L2 & Pembagian hasil usaha tidak merata antara pemilik dan ABK nelayan & 0,0344 & 4 & 0,1376 \\
\hline L3 & Tidak tersedianya data biaya operasi & 0,1034 & 2 & 0,2068 \\
\hline L4 & Pengetahuan manajemen usaha masih kurang & 0,1034 & 1 & 0,1034 \\
\hline L5 & Harga ikan tidak stabil & 0,0344 & 3 & 0,1032 \\
\hline \multicolumn{2}{|c|}{ Total } & & & 0,7578 \\
\hline \multicolumn{2}{|c|}{ Total Keseluruhan } & & & 2,6209 \\
\hline
\end{tabular}

Tabel 3. Matriks faktor eksternal

\begin{tabular}{|c|c|c|c|c|}
\hline Kode & Unsur SWOT & Bobot & Rating & Skor \\
\hline & Eksternal & & & \\
\hline & Peluang & A & B & $\mathrm{A} \times \mathrm{B}$ \\
\hline P1 & Pasar ekspor terbuka & 0,0322 & 2 & 0,0644 \\
\hline P2 & Semakin meningkatnya permintaan ikan & 0,1290 & 4 & 0,516 \\
\hline P3 & Kerjasama investasi dengan pihak lain & 0,0322 & 1 & 0,0322 \\
\hline P4 & Pengembangan pelabuhan perikanan & 0,0322 & 2 & 0,0644 \\
\hline P5 & Peningkatan kapasitas dan jumlah armada tangkap & 0,0649 & 3 & 0,1947 \\
\hline P6 & Penerapan teknologi tepat guna dalam penangkapan & 0,0967 & 2 & 0,1934 \\
\hline P7 & Terbukanya bantuan dari lembaga keuangan & 0,1290 & 3 & 0,387 \\
\hline P8 & Berfungsinya TPI dengan baik & 0,0649 & 3 & 0,1947 \\
\hline \multirow[t]{2}{*}{ Total } & & & & 1,6468 \\
\hline & Ancaman & & & \\
\hline A1 & Kelangkaan BBM & 0,1290 & 1 & 0,1290 \\
\hline A2 & Harga BBM terus meningkat & 0,0967 & 1 & 0,0967 \\
\hline A3 & Kondisi alam yang tidak menentu (gelombang, hujan dan badai, arus, dll) & 0,0322 & 4 & 0,1288 \\
\hline A4 & Terjadinya konflik antar nelayan & 0,0322 & 4 & 0,1288 \\
\hline A5 & Kenaikan biaya produksi & 0,0967 & 2 & 0,1934 \\
\hline A6 & Perubahan ruaya ikan & 0,0322 & 3 & 0,0966 \\
\hline \multicolumn{2}{|c|}{ Total } & & & 0,7733 \\
\hline \multicolumn{2}{|c|}{ Total Keseluruhan } & & & 2,4201 \\
\hline
\end{tabular}


pukat cincin di Kecamatan Tumumpa memiliki kemungkinan yang paling baik untuk dikembangkan dengan mengoptimalkan Kekuatan serta memanfaatkan Peluang. Kelemahan dan Ancaman dalam keadaan sekarang masih belum banyak memberikan pengaruh dalam pengembangan usaha.

Proses perpaduan antara Kekuatan, Kelemahan, Peluang, dan Ancaman dilakukan dengan menggunakan matriks SWOT (Tabel 4). Proses ini bertujuan untuk menentukan alternatif strategi dalam pengembangan perikanan tangkap di Kecamatan Tuminting.

\section{1) Strategi Kekuatan-Peluang $(S-O)$}

Strategi S-O merupakan strategi yang menggunakan kekuatan internal untuk memanfaatkan peluang eksternal guna memperoleh keuntungan bagi unit perikanan tangkap dalam pengembangannya. Beberapa alternatif strategi S-O yang dihasilkan antara lain:

\section{a. Meningkatkan produksi}

Strategi ini merupakan rekomendasi dari kekuatan yang dimiliki oleh unit penangkapan pukat cincin berupa produktivitasnya cukup besar dan jaringan pemasaran dekat dengan konsumen serta peluang dari pasar ekspor tersedia. Sumberdaya ikan cukup tersedia dan semakin meningkatnya permintaan ikan.

\section{b. Gunakan teknologi untuk efisiensi}

Strategi ini didasarkan pada penggunaan teknologi tepat guna untuk meningkatkan mutu ikan hasil tangkapan serta peluang terjalin investasi dengan perusahaan lain.

c. Tambah kapasitas produksi pabrik es

Strategi ini didasarkan pada kekuatan yang dimiliki unit penangkapan dimana produktivitas cukup besar, dan permintaan ikan semakin meningkat. Untuk itu diperlukan penambahan kapasitas pabrik es.

\section{2) Strategi Kelemahan-Peluang (W-O)}

Strategi W-O merupakan strategi yang disusun untuk mengatasi kelemahan dengan memanfaatkan peluang yang ada. Beberapa alternatif strategi yang dihasilkan antara lain:

a. Pelatihan untuk peningkatan kemampuan manajemen

Strategi ini untuk mengatasi kelemahan berupa pengelolaan usaha yang masih tradisional, minimnya permodalan dalam penyediaan kapal dan alat tangkap, pengetahuan manajemen usaha masih terbatas. Kelemahan tersebut dapat diatasi dengan memanfaatkan peluang-peluang yang ada berupa pasar ekspor tersedia, dan pengembangan pelabuhan perikanan.

b. Adakan kerjasama dengan lembaga keuangan

Strategi ini untuk mengatasi kelemahan berupa minimnya permodalan dalam penyediaan kapal dan alat tangkap, keterbatasan kemampuan mengakses permodalan dari lembaga keuangan rakyat. Kelemahan tersebut dapat diatasi dengan memanfaatkan peluang-peluang yang ada seperti kerjasama investasi dengan pihak lain.

c. Penyediaan data yang baik untuk evaluasi usaha

Strategi ini untuk mengatasi kelemahan berupa sulitnya mengakses permodalan dari lembaga keuangan. Kelemahan tersebut dapat diatasi dengan memanfaatkan peluang kerjasama investasi. Peluang kerjasama investasi dapat terjalin dengan baik asalkan ada pencatatan data yang baik.

\section{3) Strategi Kekuatan-Ancaman ( $S$ - $T$ )}

Strategi ini merupakan strategi yang dibuat dengan menggunakan kekuatan internal untuk menghindari atau mengurangi dampak ancaman eksternal dalam pengembangan unit perikanan pukat cincin. Strategi ini didasarkan atas tanggapan kekuatan berupa produktivitas cukup besar jaringan pemasaran dekat konsumen, jumlah nelayan cukup besar dan nelayan terampil dan berpengalaman. Faktor-faktor kekuatan tersebut dimanfaatkan dan dikembangkan untuk menanggulangi ancaman berupa kelangkaan BBM, dan terjadinya konflik antar nelayan.

\section{4) Strategi Kelemahan-Ancaman (W-T)}

Strategi ini merupakan strategi yang diusulkan untuk mengurangi kelemahan internal dan mengurangi ancaman eksternal yang ada. Strategi ini disusun untuk mengantisipasi kelemahan seperti pendapatan nelayan kecil, dan armada tangkap yang memiliki daya jangkau rendah. Kelemahan-kelemahan tersebut perlu diperbaiki untuk menghindari ancaman berupa kondisi alam yang tidak menentu, dan konflik antar nelayan.

Selanjutnya strategi yang sudah dirumuskan ditentukan prioritas pelaksanaannya dengan melihat keterkaitan antar faktor yang mendukungnya sehingga diperoleh rekomendasi 
berdasarkan prioritas. Hasil analisis perumusan ini disajikan pada Tabel 5.

\section{Pembahasan}

\section{Strategi $S-O$}

Hasil perumusan strategi pada Tabel 3 dan prioritasnya pada Tabel 4 memberikan gambaran bahwa ada 3 strategi S-O, yakni meningkatkan produksi, menggunakan teknologi untuk efisiensi dan menambah kapasitas produksi pabrik es.

Peningkatan produksi yang perlu dilakukan yakni dengan meningkatkan kemampuan tangkap setiap kapal pukat cincin yang beroperasi tanpa perlu dilakukan penambahan unit penangkapan. Hal ini menjadi pertimbangan karena data hasil penelitian menunjukkan bahwa sebagian besar kapal pukat cincin menghasilkan tangkapan masih di bawah rata-rata.

Dengan demikian pertambahan produksi cukup dilakukan dengan menaikkan kapasitas tangkap yang tentu saja upaya ini harus ditunjang dengan pemanfaatan teknologi seperti menggunakan alat bantu penangkapan berupa fish finder atau echosounder, di samping penggunaan winch dengan kapasitas yang cukup untuk efisiensi waktu dalam penarikan tali cincin.

Penambahan kemampuan tangkap juga dapat dilakukan dengan memperluas jangkauan daerah penangkapan. Namun upaya ini akan menambah waktu operasi sehingga dibutuhkan kapasitas es yang cukup.

Tabel 4. Model matriks analisis SWOT

\begin{tabular}{|c|c|c|}
\hline Faktor Eksternal & $\begin{array}{l}\text { Strength (Kekuatan) } \\
\text { - Produktifitas cukup besar } \\
\text { - Jaringan pemasaran dekat dengan } \\
\text { konsumen } \\
\text { - Jumlah nelayan cukup besar } \\
\text { - Jangkauan alat tangkap luas dalam } \\
\text { menangkap ikan } \\
\text { - Memiliki nilai analisis usaha yang } \\
\text { menguntungkan } \\
\text { - Tersedianya kapal, alat tangkap dan } \\
\text { rumpon } \\
\text { - Tersedianya galangan kapal rakyat } \\
\text { - Tersedianya pabrik es }\end{array}$ & $\begin{array}{l}\text { Weakness (Kelemahan) } \\
\text { - Tidak ada pencatatan dan penyajian } \\
\text { data tangkap nelayan } \\
\text { - Pembagian hasil usaha tidak merata } \\
\text { antara pemilik dan ABK nelayan } \\
\text { - Tidak tersedia biaya operasi } \\
\text { - Pengetahuan manajemen usaha } \\
\text { masih kurang } \\
\text { - Harga ikan tidak stabil }\end{array}$ \\
\hline $\begin{array}{l}\text { Opportunity (Peluang) } \\
\text { - Pasar ekspor terbuka } \\
\text { - Semakin meningkatnya permintaan } \\
\text { ikan } \\
\text { - Kerja sama investasi dengan pihak } \\
\text { lain } \\
\text { - Pengembangan pelabuhan perikanan } \\
\text { - Peningkatan kapasitas dan jumlah } \\
\text { armada tangkap } \\
\text { - Penerapan teknologi tepat guna dalam } \\
\text { penangkapan } \\
\text { - Terbukanya bantuan dari lembaga } \\
\text { keuangan } \\
\text { - Berfungsinya TPI dengan baik } \\
\end{array}$ & $\begin{array}{l}\text { Kebijakan SO } \\
\text { - Meningkatnya produksi } \\
\text { - Gunakan teknologi untuk efisiensi } \\
\text { - Tambah kapasitas produksi pabrik es }\end{array}$ & $\begin{array}{l}\text { Kebijakan WO } \\
\text { - Pelatihan untuk peningkatan } \\
\text { kemampuan manajemen } \\
\text { - Adakan kerjasama untuk lembaga } \\
\text { keuangan } \\
\text { - Penyediaan data yang baik untuk } \\
\text { evaluasi usaha }\end{array}$ \\
\hline $\begin{array}{l}\text { Threat (Ancaman) } \\
\text { - Kelangkaan BBM } \\
\text { - Harga BBM terus meningkat } \\
\text { - Kondisi alam yang tidak menentu } \\
\text { - Terjadinya konflik antar nelayan } \\
\text { - Kenaikan biaya produksi } \\
\text { - Perubahan ruaya ikan }\end{array}$ & $\begin{array}{l}\text { Kebijakan ST } \\
\text { - Minta dukungan pemerintah untuk } \\
\text { menelusuri supply BBM } \\
\text { - Tingkatkan keuntungan melalui } \\
\text { penyesuaian harga } \\
\text { - Tingkatkan ketrampilan nelayan } \\
\text { - Perlu analisis jumlah rumpon yang } \\
\text { layak dipasang }\end{array}$ & $\begin{array}{l}\text { Kebijakan WT } \\
\text { - Perbesar armada tangkap untuk } \\
\text { menjangkau daerah penangkapan } \\
\text { yang lebih luas } \\
\text { - Tingkatkan fungsi TPI untuk } \\
\text { menjaga stabilitas harga } \\
\text { - Perlu pengawasan wilayah laut } \\
\text { - Perlu analisis CPUE untuk } \\
\text { mengamati perkembangan potensi }\end{array}$ \\
\hline
\end{tabular}


D.M. Puansalaing dkk.

Tabel 5. Penentuan prioritas strategi

\begin{tabular}{lllc}
\hline Strategi & Keterkaitan & Skor & Rangking \\
\hline Meningkatkan produksi & K1, K2, K4, P1, P2, P3, P8 & 1,8773 & 1 \\
Mengunakan teknologi untuk efisiensi & K1, K5, P4, P5 & 1,0889 & 3 \\
Menambah kapasitas produksi pabrik es & K1, K5, K7, K8, P1, P2, P5 & 1,777 & 2 \\
Melaksanakan pelatihan untuk peningkatan kemampuan manajemen & L1, L2, L3, L4, P6, P7 & 1,235 & 5 \\
Mengadakan kerjasama untuk lembaga keuangan & L2, L5, P1, P3, P7 & 0,7244 & 11 \\
Menyediakan data yang baik untuk evaluasi usaha & L1, L3, P3, P7 & 0,8328 & 9 \\
Meminta dukungan pemerintah untuk menelusuri supply BBM & K4, K5, A1, A2, A3 & 0,7343 & 10 \\
Meningkatkan keuntungan melalui penyesuaian harga & K1, K2, K6, A5, A6 & 1,3256 & 4 \\
Meningkatkan ketrampilan nelayan & K3, K4, K8, A1, A5, A6 & 0,8667 & 8 \\
Memerlukan analisis jumlah rumpon yang layak dipasang & K1, K5, A6 & 0,9264 & 6 \\
Memperbesar armada tangkap untuk menjangkau daerah & L1, L2, A3, A6 & 0,5698 & 12 \\
penangkapan yang lebih luas & L5, A4, A5 & 0,4254 & 14 \\
Meningkatkan fungsi TPI untuk menjaga stabilitas harga & L1, A3, A6, A4 & 0,561 & 13 \\
Melakukan pengawasan wilayah laut & L1, L3, L4, A2, A5, A6 & 0,9037 \\
Melakukan analisis CPUE untuk mengamati perkembangan potensi & & & 7 \\
\hline
\end{tabular}

\section{Strategi $\mathrm{W}-\mathrm{O}$}

Hasil perumusan strategi pada Tabel 3 dan prioritasnya pada Tabel 4 memberikan gambaran bahwa ada 3 strategi W-O, yakni pelatihan untuk peningkatan kemapuan manajemen, adakan kerja sama untuk lembaga keuangan, dan penyediaan data yang baik untuk evaluasi usaha.

Pelatihan untuk peningkatan kemampuan manajemen perlu dilakukan untuk membantu dalam pengelolaan usaha yang baik. Sulitnya mengakses permodalan dari lembaga keuangan, merupakan salah satu kendala yang manghambat perkembangan usaha. Ada banyak peluang kerja sama, tetapi dalam hal ini dibutuhkan pencatatan data yang baik. Pencatatan data yang baik sangat dibutuhkan dalam menjalin kerja sama dengan perusahaan lain.

\section{Strategi $S-T$}

Hasil perumusan strategi pada Tabel 3 dan prioritasnya pada Tabel 4 memberikan gambaran bahwa ada 4 strategi S-T, yakni meminta dukungan pemerintah untuk menelusuri supply BBM, tingkatkan keuntungan melalui penyesuaian harga, tingkatkan ketrampilan nelayan, dan buat regulasi zona penangkapan.

Peningkatan produksi dipengaruhi juga oleh ketrampilan nelayan. Ketrampilan nelayan perlu ditingkatkan tidak hanya dalam penggunaan alat tradisional tapi perlu juga dilatih dalam penggunaan teknologi yang baru agar lebih efisien.

\section{Strategi $W-T$}

Hasil perumusan strategi pada Tabel 3 dan prioritasnya pada Tabel 4 memberikan gambaran bahwa ada 3 strategi W-T, yakni perbesar kapal penangkap untuk menjangkau daerah penangkapan yang lebih luas, tingkatkan fungsi TPI untuk menjaga stabilitas harga, dan perlunya pengawasan wilayah laut.

Pengawasan wilayah laut perlu dilakukan untuk mengawasi nelayan asing yang masuk serta mencegah terjadinya konflik antar nelayan.

\section{KESIMPULAN}

Keadaan perikanan di Kecamatan Tuminting pada umumnya masih dalam taraf membangun dan memajukan. Alat tangkap yang paling dominan dan dianggap bersifat komersil adalah pukat cincin. Pusat perikanan pukat cincin terletak di Kelurahan Tumumpa Dua, tepatnya di Pelabuhan Perikanan Tumumpa. Komponen masyarakat yang melakukan usaha perikanan di lingkungan pelabuhan antara lain adalah nelayan, pemilik kapal, penjual ikan, pengusaha, tenaga kerja bongkar muat, dan pengurus kapal.

Strategi pengembangan unit penangkapan pukat cincin di Kecamantan Tuminting adalah: 1) Meningkatkan produksi; 2) Menggunakan teknologi untuk efisiensi; 3) Menambah kepasitas produksi pabrik es; 4) Melaksanakan pelatihan untuk peningkatan kemampuan manajemen; 5) Mengadakan kerjasama untuk lembaga keuangan; 6) Menyediakan data yang baik untuk evaluasi usaha; 7) Meminta dukungan pemerintah untuk menelusuri supply BBM; 8) Meningkatkan keuntungan melalui penyesuaian harga; 9) Meningkatkan ketrampilan nelayan; 10) Meningkatkan fungsi TPI untuk menjaga stabilitas harga; 11) Memerlukan pengawasan wilayah laut; 12) Membuat regulasi zona penangkapan; dan 13) 
Memperbesar armada tangkap untuk menjangkau daerah penangkapan yang lebih luas.

\section{DAFTAR PUSTAKA}

Elier, E. 2007. Kajian teknologi penangkapan ikan yang memberi pendapatan nelayan yang layak di Pelabuhan
Perikanan Nusantara Pelabuhan Ratu Sukabumi. Tesis. Sekolah Pascasarjana IPB, Bogor.

Fauzi, A. dan S. Anna. 2005. Permodelan Sumberdaya Perikanan dan Kelautan untuk Analisis Kebijakan. PT Gramedia Pustaka Utama, Jakarta.

Rangkuti, F. 2006. Analisis SWOT Teknis Membedah Kasus Bisnis. PT Gramedia Pustaka Utama, Jakarta.

Undang-undang Republik Indonesia Nomor 31 Tahun 2004 Tentang Perikanan. 